Tomasz Tadeusz Brzozowski

Wałbrzyska Wyższa Szkoła Zarządzania i Przedsiębiorczości

Centrum Kształcenia Ustawicznego przy Zakładzie Karnym nr 1 we Wrocławiu

Autorskie Licea Artystyczne i Akademickie ALA we Wrocławiu

\title{
Globalizacja a wykluczenie społeczne Etyczna i kulturowa geneza procesu marginalizacji
}

\section{Problematyczność zjawiska globalizacji}

Globalizacja, od samego początku funkcjonowania tego pojęcia w literaturze, uwikłana jest w szereg zależności, w wyniku których pojawiły się pytania o ryzyko związane z jej przebiegiem, intensywnością, a przede wszystkim - skutkami. Jako proces otwarty jest ona narażona na sprzeczności wewnętrzne i głównie to przyczyniło się do trudności w przewidywaniu i kontroli jej przebiegu. Zachodzące procesy globalne, sprowadzone przez badaczy różnych dziedzin do dość wygodnego pojęcia globalizacja, z czasem ujawniły swe ryzyko. Jest to skutek faktu, że dynamika tych procesów spowodowała trwałe, jak się wydaje, zmiany w dziedzinach społecznej, gospodarczej i kulturowej. Postawiło to badaczy tego zjawiska przed potrzebą rozwiązania całkiem nowych, niedających się przewidzieć w niedalekiej przeszłości, problemów. Ich źródła do dziś pozostają niewyjaśnione, bowiem są rezonansem wielu nawarstwiających się procesów i zjawisk, mających określone skutki w różnych sferach rzeczywistości.

Problem i skala ryzyka, na które został narażony współczesny świat pod wpływem przetaczającej się fali procesów globalnych, pozwala na sformułowanie kilku uwag. Po pierwsze, globalizacji zagraża ryzyko zewnętrzne, przez co można rozumieć szereg niepokojących zmian, które zachodzą na skutek oddziaływania świata przyrodniczego. Niektórzy badacze twierdzą, że to ryzyko zostało już w znacznym stopniu opanowane, co dokonało się głównie za przyczyną wzmożonego rozwoju techniki, będącej skutecznym instrumentem przewidywania zjawisk przyrody oraz neutralizującym jej zapędy (Giddens 2008, s. 87). Czy rzeczywiście? Coś, co dla niektórych naukowców jest już pieśnią przeszłości, z całą mocą ukazuje ich błędne przekonania. Jeśli odniesiemy się do obserwowalnych zjawisk ocieplenia klimatu, ruchów tektonicznych, których niepodobna przewidzieć, nagłego wzrostu poziomu rzek czy nieuzasadnionych geologicznie uaktywnień dawno wygasłych wulkanów - kwestia nie jest już tak jednoznacznie oczywista. Dodatkowo problem potęguje fakt zwielokrotnienia występowalności tych zjawisk, który w XXI w. przybrał skalę regularności.

Nieco inaczej akcenty rozkładają zwolennicy tezy o ryzyku stwarzanym przez człowieka. Nie bez znaczenia w tej kwestii pozostaje stwierdzenie, że najbardziej nieprzewidywalnym „czynnikiem” mającym wpływ na rzeczywistość postaje sam człowiek. Otóż stanowisko to uznaje, że globalizacja zagrożona jest skutkami działań człowieka. Najczęściej podnosi się $\mathrm{w}$ tej kwestii problem ingerencji w środowisko naturalne, za którym stoi wiedza oraz technika (Giddens 2008, s. 87). Inwazyjność techniki penetrującej bezrefleksyjnie środowisko naturalne stwarza dodatkową obawę o stan zdrowia społeczeństwa. Można to ująć w starej maksymie 
nihil novi sub Solis. Na tego typu zagrożenia wskazywali już dawno inni badacze. Jednym z najprzenikliwszych był Oswald Spengler, już w 1918 r. przewidujący upadek kultury zachodniej, do którego przyczynić się miała w dużej mierze technika. Technika, choć wytwór myśli ludzkiej, a więc tryumf racjonalizmu nad irracjonalizmem świata przyrody, szybko ukazała swe drugie oblicze: z początkowego sprzymierzeńca ludzkości z coraz większą mocą stawała się jego wrogiem (Brzozowski 2003). Zwycięstwo mikrokosmosu nad makrokosmosem i uznanie wyższości tego pierwszego sprawiło, że człowiek bardzo szybko przekształcił się w niewolnika swego tworu (Spengler 2001, s. 441) i takim oto sposobem technika wdarła się w świat, zaś skutki tej ingerencji, miast poprawić jakość życia społeczeństw, coraz bardziej niepokoją.

Pozostać na poziomie obaw wynikających $\mathrm{z}$ procesu globalizacji $\mathrm{w}$ sferze zagrożenia ze strony techniki, to nie dostrzegać bardziej istotnych, bo odpowiedzialnych za zmiany w obrębie samego człowieka skutków. Problem dotyczy wpływu procesów globalnych na kwestie społeczne i kulturowe, z których najgroźniejszymi, jak sądzę, są osamotnienie, nierówność i spłycenie relacji interpersonalnych. Stopień oddziaływania procesów globalnych na społeczeństwo jest ogromny i choć widzi się go głównie w odniesieniu do czynników makrospołecznych, w nie mniejszym stopniu ujawnia się w obszarach mezostruktury, a przede wszystkim - mikrostruktury, spośród której najwrażliwszą społecznie i kulturowo jest rodzina.

\section{Czy moralność da się zglobalizować?}

W kontekście dotychczasowych rozważań można zadać pytanie: Czy procesy globalne są W stanie tak silnie oddziaływać na naszą rzeczywistość, iż mogą zmienić porządek moralny społeczeństw i tworzących je jednostek? Jednoznaczna odpowiedź na to pytanie byłaby zbyt ryzykowna, ale można pokusić się o próbę częściowej odpowiedzi. Współcześnie niepokój budzi wiele zmian zachodzących szczególnie w mentalności współczesnego człowieka i wcale nie chodzi o to, aby bić na alarm i za wszelką cenę starać się ratować etykę w jej klasycznym kształcie. Zmiany, zarówno w świadomości, jak i zachowaniach ludzi wobec nieustannie zmieniającej się rzeczywistości, to nieuchronny wynik postępujących procesów społecznych, które im towarzyszą. Dlatego mówić o nich jako o czymś z gruntu niewłaściwym jest bezzasadne. Bardziej pożądanym jest więc określenie ich genezy i próba zrozumienia zjawisk, których, podobnie jak procesu globalizacji, zatrzymać się nie da. Można co najwyżej postarać się je zrozumieć lub przewidzieć, w jakich kierunkach zmiany te będą zdążać. Jedną z nich, wynikającą w moim przekonaniu wprost z procesów globalnych, jest indywidualizm. Choć indywidualizm jako postawa wobec otaczającej podmiot rzeczywistości znany jest od starożytności, ujmowany społecznie, budzi zastrzeżenia. Podkreślić od razu należy, że indywidualizm w sensie etycznym może być rozpatrywany adiaforycznie, bowiem podążanie z góry wytyczoną przez siebie drogą nie musi oznaczać, że w takim sposobie egzystencji czai się zło. Naturalny indywidualizm - osiągnięcie współczesnej cywilizacji - pozwala na autozdefiniowanie się jednostki i wolny wybór kształtu, jakości i sposobów realizacji swego człowieczeństwa. Ale współczesne pojęcie wolność charakteryzuje się zdecydowanym wykroczeniem poza dotychczasowe, tj. wypracowane przez powszechną racjonalność moralne horyzonty (Taylor 2002, s. 10). Porzuciwszy je, ludzie przyjęli zupełnie nowe wzorce oparte głównie na kryterium ekonomicznym, odrzucając hierarchicznie uporządkowaną wizję społeczeństwa oraz zmieniając model nowoczesnej rodziny. Innym, ważnym aspektem indywidualizmu jest zawężenie pola wiedzenia. Redukcja dotyczy nie tylko świata przyrody, ale nade wszystko innych ludzi oraz wypracowanych przez nich wartości. 
W przeszłości ludzie odnosili się do świata w kontekście jego dziejów, zatem jawił się im on jako szerokie pasmo dokonań i wartości wypracowanych przez ludzkość. Ważną rolę w tej wizji odgrywał porządek hierarchiczny, którego odbiciem stawał się układ społeczny, gdzie jedni dominowali, inni zaś byli zdominowanymi. Tak zarysowana struktura społeczna odzwierciedlała porządek całego wszechświata. Hierarchiczność, choć w znacznym stopniu determinująca wolność jednostki, wolność rozumianą jako prawo do wyboru sposobu życia, nadawała sens światu oraz stosunkom międzyludzkim. Ci, którzy podlegali hierarchii, nie pełnili jedynie roli podrzędnej, wypełniając tym samym strukturę w sensie pustych i pozbawionych znaczenia elementów, ale byli obdarzeni samodzielnym znaczeniem, które wynikało z miejsca zajmowanego w tej uformowanej w pewnym porządku całości. Jeśli przeniesiemy się na obszar praktyk społecznych w ich obrzędowości, które organizowały i do dziś, choć w innym sensie, organizują relacje społeczne, to ich przeżywanie wiązało się z autentycznym (magicznym) przeżywaniem wyjątkowego i nadzwyczajnego wydarzenia $z$ historii, które obrzęd ten zachowywał i upamiętniał. Dziś tego typu przeżycia stają się dla większości odbiorców kultury obce. Wskazują na to m.in. badania socjologiczne, śledzące np. intensywność przeżyć religijnych podczas obchodzenia świąt (Baniak 2007). Symbolika i oprawa coraz częściej przejmują rolę instrumentu, dzięki któremu możliwym stają się spotkania w gronie rodzinnym, a sposób przeżywania (styl obchodzenia), z Eliadowskim odzyskiwaniem utraconego lub przeszłego czasu niewiele mają wspólnego.

Jak zauważa Ulrich Beck, nowoczesność, choć się radykalizuje, to na obrzeżach pozostawia stare elementy nowoczesnej kultury, które świadczą m.in. o tym, że nie powstał żaden jakościowo nowy ład społeczny. Mimo iż postnowoczesne społeczeństwo stara się je zachować i uchronić przed wymazaniem, nie są one już przydatne dla współczesnej rzeczywistości, ona już tych instytucji nie potrzebuje i równie dobrze potrafi się bez nich obejść. Tak też poprzedni ład nijak ma się do nowych czasów. Nowoczesność, w swym radykalizmie, zapomniała lub zagubiła potrzebę ukonstytuowania nowego, bardziej do obecnych wymagań społecznych adekwatnego ładu. Zdezawuowano wszelkie granice, aby sprostać rodzącym się z coraz większą mocą napięciom związanym z radykalizacją, ale w taki sposób rodzą się nowe i bardziej zagrażające ludziom ryzyka (Beck 2002). W kontekście dyskutowanych dziś problemów można zadać pytanie o jakość i wartość tych przemian. W sytuacji utraty horyzontów społecznych, nadających wartość i wagę naszym jednostkowym wyborom, utraciliśmy „heroiczność” życia. Jakie cele i wartości są dziś w stanie spowodować, że warto za nie oddać życie?

Powyższy problem, zdaniem Charlesa Taylora, związany jest z kwestią zawężenia horyzontów: „Ludzie utracili szerszą wizję rzeczywistości, ponieważ skupili się na swoim własnym, indywidualnym życiu [...]. [...] ciemną stroną indywidualizmu jest skupienie się na sobie, co zarazem spłaszcza i zawęża nasze życie, czyniąc je mniej znaczącym i mniej związanym z innymi ludźmi czy społeczeństwem" (Taylor 2002, s. 12). Zawężenie horyzontów nadających jednostce niepowtarzalne poczucie uczestnictwa w wielowiekowym procesie humanizacji rzeczywistości sprowadza się do tego, że jednostka przeżywa swe życie jako wykorzeniona w sensie społecznym i kulturowym. To najbardziej odczuwalna bolączka naszych czasów, które charakteryzują narcystyczno-egotyczne zachowania. Społeczeństwo permisywne, przyzwalając na wszelkie wybory swych członków, nie interesując się ich życiem prywatnym oraz pozwalając im na swobodny wybór modelu życia rodzinnego i manifestowanie nietypowych zachowań seksualnych, w sposób najbardziej dla siebie naturalny posługuje się racjonalnością instrumentalną. Warto scharakteryzować ten model rozumienia świata, bowiem jest on na tyle powszechny, że stanowi kolejny czynnik ryzyka wynikającego z procesów globalnych i w nie mniejszym stopniu przyczynia się do problemu marginalizacji. 
Pojęciem rozum instrumentalny posługuje się Charles Taylor, definiując go jako rodzaj racjonalności „którym posługujemy się, aby wyliczyć najbardziej ekonomiczny sposób wykorzystania środków prowadzących do danego celu. Maksymalna efektywność, najlepsza relacja nakładów do zysków - oto kryterium sukcesu takiego rozumowania" (Taylor 2002, s. 12). Odstukturalizowane społeczeństwo, bo pozbawione umocowania, które w odczuciu powszechnej świadomości znacznie ograniczało zakres jednostkowej wolności, utraciło cenne narzędzie kulturowe, jakim była busola moralna. Wykorzeniona świadomość „niczyjości” formuje teren dla podejmowania często rozpaczliwych prób mających nadać sens jednostce odrzucającej dorobek poprzednich pokoleń w sensie wypracowanych zachowań kulturowych i obyczajowości. Pojawiający się w tym miejscu rozum instrumentalny bardzo szybko przejął nowy paradygmat osiągania szczęścia. Dokonana wolta kulturowa, spychająca na dalszy plan horyzonty znaczeniowe, zawęziła pole działania jednostki, ograniczając jej zainteresowania do wygody, egoistycznie pojmowanego szczęścia mającego być gwarantem dobrobytu.

Kryteria, którymi operuje racjonalność instrumentalna, polegają głównie na przejęciu całości władzy interpretacyjnej i podporządkowaniu jej wielości pozapodmiotowej, uczyniwszy z niej uprzednio jedynie narzędzia wspomagające człowieka w trudzie zdążania do dobrobytu. Tedy więc zarówno fauna, jak i flora są wykorzystywane jedynie pod kątem zadowolenia i szczęścia człowieka. Tak więc rozum instrumentalny, uwolniwszy się pierwej od ograniczających jego zapędy dokonań ludzkości, samodzielnie, tj. bez liczenia się z podmiotowością innych elementów rzeczywistości (odmówił im prawa do samostanowienia i wolności w pozostawaniu w zgodzie ze stanem natury), przejął całkowitą kontrolę, włączając w obszar swego oddziaływania samego człowieka. Poszerzając zakres wpływów, z czasem zaczął zagrażać ludzkości.

Jednostkowe wybory uwzględniające zupełnie inne (możliwe, że odmienne) kryteria, zostały zmarginalizowane, ponieważ nie zgadzały się z kryterium najważniejszym, mianowicie z ekonomicznością. Racjonalność instrumentalna zaprowadziła zatem swoistą dyktaturę wyboru obliczoną przede wszystkim na uwzględnienie efektywności celu. Stąd obawa, że suwerenne cele, które powinny kierować naszym życiem, zostaną przesłonięte przez postulat maksymalizacji wydajności (Taylor 2002, s. 13). Ujawnienie się odpersonalizowanych, bo operujących głównie statystyką i wykresem, sił w społeczeństwie wyznaczyło nowy biegun dla postępowania człowieka współczesnego, nakazując mu przed dokonaniem wyboru (przede wszystkim o charakterze moralnym) uwzględnienie analizy kosztowo-celowej. Chcąc sprostać temu zadaniu, człowiek sięgnął po narzędzie, mające go wspomóc na drodze rozwoju społecznego po technikę. Ta, z czasem zaczęła zagrażać jego podmiotowości, bowiem stopień uzależnienia postępuje i zmierza w kierunku, na którego krańcach pojawia się implicite postulat częściowej eliminacji człowieka, który z punktu widzenia ekonomii nie zawsze okazuje się opłacalny (Rifkin 2001).

Kwestię zmniejszającego się zapotrzebowania na pracę podejmuje kontrowersyjna książka Koniec pracy. Jej autor - Jeremy Rifkin - zajął stanowisko zgodne z opinią grup socjalistycznych pesymistów twierdzących, że zaawansowana technologia w efekcie doprowadzi do koncentracji bogactwa w rękach wąskich elit, co znacząco wpłynie na globalne bezrobocie mas. W tej perspektywie w niedalekiej przyszłości zabraknie pracy nie tylko dla grupy przejściowo bezrobotnych, ale dla stałej populacji wyłączonych na trwale z uczestnictwa w życiu społecznym. Ich liczba będzie znacząca nie tyle dla poszczególnych społeczeństw, ile w skali globalnej. Innym źródłem wykluczenia staje się ,„paradygmat przyrządu”. Określenie to odnosi się do ściśle sprofilowanych dóbr konsumpcyjnych, wyłączających w sensie przeznaczenia inne możliwości ich użytkowania. Problem wiąże się z rezygnacją z wielokierunkowych 
relacji na rzecz konkretnego i w niczym nie powiązanego z innymi czynnościami i ludźmi produktu. Na ten problem zwraca uwagę Albert Borgman, który podaje przykład zmian technologicznych w kontekście ogrzewania domów. Wskazuje, że w przeszłości proces ten wymagał sporego zaangażowania wielu członków rodziny zamieszkującej wspólnie jeden budynek, jedni wyszukiwali drzewa jako źródła energii i opału, inni je rąbali, jeszcze inni przenosili na miejsce składowania. Ktoś z rodziny trudnił się rozpalaniem, ktoś czuwał, aby nieustannie drzewo podkładać. Sytuacja diametralnie się zmieniła, gdy wprowadzono piece centralnego ogrzewania, eliminujące nie tylko potrzebę zatrudnienia ludzi, ale także ich zatroskanie o wspólne dobro. Poza wygodą, jaką niewątpliwie okazało się to rozwiązanie, zaprzepaszczono wspólny wysiłek integrujący na co dzień rodzinę oraz budujący relacje dobrosąsiedzkie (Borgman 1984).

Weberowska żelazna klatka daje o sobie znać szczególnie w sytuacjach, gdy zakusy racjonalności instrumentalnej, poprzez jej ekspansywny charakter, rozciągają się na coraz to rozleglejsze sfery życia. Opresywność rozumu instrumentalnego dotyka przede wszystkim tych, którzy nie potrafią lub nie chcą przeciwstawić się na co dzień dojmującemu ciśnieniu społecznego przymusu. Toteż wiele osób, np. należących do świata biznesu, nie akceptując z subiektywnego punktu widzenia niektórych rozpowszechnionych i okrzepłych w tym środowisku zasad, ulega presji większości, mody lub narzuconych często standardów, resztki swej wolność pozostawiając i demonstrując w osobistych komentarzach krytycznych wygłaszanych w zaciszu swego domu lub w wąskiej grupie przyjaciół. Biznesowi obce jest oddanie się lub poświęcenie czemuś tak dla człowieka oczywistemu, co naturalnemu jak rodzina. Szczególnie kobiety, budując swe pozycje społeczne i zawodowe, przemierzając zaplanowane uprzednio szczeble kariery, choć w poczuciu tego, że je coś ważnego omija (macierzyństwo, rodzina), dokonują mimo to wyborów pod presją i przymusem społecznych oczekiwań rynkowych. Efektywność i analiza kosztowo-celowa pozbawia je tego, z czym w głębi sumienia się często nie zgadzają, ograniczając znacznie margines ich wolności. O ile celne, z punktu widzenia biznesu, wybory skutkują pożądanym efektem ujawniającym się w postaci oczekiwanego zysku lub sukcesu w karierze, o tyle nieudane i nietrafne posunięcia ludzi degradują i wykluczają ich jako przydatnych dla społeczeństwa.

W Taylorowskiej analizie nowoczesnych zjawisk i zachowań społecznych, spośród czynników odpowiedzialnych za erozję dialogicznych relacji interpersonalnych obok indywidualizmu i rozumu instrumentalnego znajdują się struktury społeczeństwa industrialno-technicznego ograniczające w odczuwalny sposób nasze codzienne wybory. Wymuszają one na uczestnikach życia społecznego dezawuowane w sposób dla ludzi naturalny racje, zadając gwałt naszej wolności. Dla tego typu przekonań, w toku poważnych przemyśleń moralnych prawdopodobnie nigdy nie byłoby $z$ naszej strony akceptacji. Jeśli jednak się ona pojawia, to następuje jako skutek przymusu, który ma źródło w racjonalności instrumentalnej, a więc w określonych sposobach przeżywania świata poddanych do wierzenia i zastosowania w praktyce, sporządzonych w ściśle określonym i doraźnym celu. Można zadać, myślę, bardzo zasadne pytanie: Kto stoi za takimi ideami? Bezduszne i nieczułe mechanizmy kierujące światem? Czy może mimo wszystko ludzie? Skoro mówimy o racjonalności jako narzędziu mającym doprowadzić do określonego skutku, to w sposób naturalny wydaje się, że ten właśnie rodzaj racjonalności, o ile zaistniał w przestrzeni społecznej, mógł się zrodzić i wyjść jedynie z innej racjonalności.

W tym miejscu należałoby odpowiedzieć na postawione na początku tego podrozdziału pytanie: Czy moralność, jako określony sposób naszego zachowania wobec innych i otaczającej nas rzeczywistości, za które każdy z nas jest odpowiedzialny, może ulec wpływowi procesów globalnych rodzących wyraźne i odczuwalne zmiany w różnych sferach życia? 
Pytanie jest interesujące, bo wikła nas m.in. w problemy zależności etyki i moralności, które najczęściej w odbiorze społecznym traktowane są jako tożsame. Etyka jako nauka o moralności, w bogatej historii swej dyscypliny, zawiera szereg możliwych odpowiedzi skodyfikowanych $\mathrm{w}$ formie zaleceń, twierdzeń i normatywnych regulacji. Toteż w tym sensie stanowi rezerwuar różnych stanowisk wypracowanych w toku historycznych debat społecznych. Mimo to są one w odwrocie, bowiem jako akty normatywne, ściśle regulujące postępowanie człowieka, z uwagi na swą skostniałą formę, zastygłą w niezmiennych formach nakazów i zakazów utraciły dziś swą atrakcyjność. Powodem tego jest, jak sądzę (poza piewcami tzw. etyki sytuacyjnej) m.in. pominięcie w nich elastyczności.

Określenie flexibility odniesione np. do walki z rutyną i skostniałymi formami działań ludzkich ma raczej pozytywne konotacje, ale w perspektywie zmian kulturowych czy społecznych ten dodatni wydźwięk traci na ostrości. Elastyczność oznacza dziś otwarcie na zmiany, innowatykę zachowań, łatwość przystosowywania się do nowych i zmiennych warunków. Elastyczność, jak powiada Sennett, opiera się na trzech zasadniczych elementach. Są nimi: wymyślanie instytucji od nowa, elastyczna specjalizacja produkcji oraz koncentracja władzy bez jej centralizacji (Sennett 2006). Pierwsze prowadzi do przeprojektowania instytucji w sposób gwałtowny i nieodwracalny, podczas którego usuwa się nić wiążącą przeszłość danej organizacji z jej teraźniejszością. Nietrudno się domyślić, że takie praktyki polegają na sporych oszczędnościach w dziedzinie kapitału ludzkiego, co pociąga za sobą masowe zwolnienia z pracy (reeingeering, downsizing). Z kolei zadaniem elastycznej specjalizacji jest jak najszybsze dostarczenie na rynek zróżnicowanych pod względem jakościowym i ilościowym produktów. Zatem funkcjonalizm produkcji elastycznej jest zależny od tego, jak dane społeczeństwo definiuje dobro wspólne. Nie jakość produktu i jego pożądany wpływ np. na zdrowie konsumenta stanowi główne kryterium, ale aktualny gust klienta, pod którego profiluje się produkt. Koncentracja bez centralizacji, mająca pozory wolności i samorządności, w efekcie reorganizuje strukturę organizacji w taki sposób, by stwarzać iluzję małych segmentów przypominających układ sieciowy (usieciowienie relacji interpersonalnych). Kontrole sprawuje się zazwyczaj przez wyznaczenie określonych celów. Kiedy te nie są osiągane, następuje tzw. dociskanie zespołów. Problem w tym, że jednostka nadzorująca podaje podległym zespołom jedynie wskazówki, precyzując wymagania, bowiem ludziom z nadzoru brak niekiedy kompetencji merytorycznych, których zresztą nikt od nich nie wymaga.

Problem rozbija się więc o zakres odpowiedzialności za wyniki pracy zespołowej. W takiej strukturze przypisanie w sposób jednoznaczny komuś odpowiedzialności, w praktyce jest niemożliwe. Najczęściej więc na wynik grupy pracuje kilka osób, zaś brak skutecznych instrumentów pomiaru indywidualnej odpowiedzialności za efekt pozwala na swobodne korzystanie wszystkich z zespołu z dobrodziejstwa skutków wysiłku niewielu. Gmatwanina konstrukcji piramidalnych nadzorujących poszczególne zespoły (teamwork), zaciera rzeczywiste granice nie tyle odpowiedzialności, co zależności między ludźmi, obniżając tym samym wartość naturalnych więzi między pracownikami i prowadząc do poczucia wyobcowania i izolacji (Sennett 2002).

W warunkach globalizującej się rzeczywistości określone wymagania stawia się również etyce. O ile na elastyczność w zakresie etyki normatywnej nie ma co liczyć, o tyle pożądanym stają się wszelkie regulacje o kwalifikacjach moralnych, które, wychodząc na przeciw nowoczesnym zapotrzebowaniom, uwzględniałyby postulat elastyczności w odniesieniu do kwestii moralnych wyborów jednostki, sankcjonując tym samym niezgodne z osobistymi odczuciami posunięcia. Takie teorie wpływają łagodząco na wszelkie przejawy dysonansu moralnego w sytuacjach konfliktowych. 
Rynek pracy, który niewątpliwie jest jednym z najwrażliwszych i podatnych na zmiany wynikające $\mathrm{z}$ procesów globalnych, ujawnia zanik tradycyjnych modeli kariery. Wykorzystanie nabytego kiedyś wykształcenia, związanego z wąską specjalizacją lub określonymi umiejętnościami, nie chroni przed zmianami, ale staje się źródłem wielu niepowodzeń i frustracji. Człowiek w wieku szkolnym musi tak planować swą karierę (co stanowi czynnik wysokiego ryzyka), aby w czasie procesu kształcenia był zdolny do jego uzupełnienia o całkiem nowy, niewykluczone, że w żaden sposób niezwiązany z dotychczasowym lub niedawno zdobytym, profil. Współcześnie korporacje zlecają małym podmiotom, często jednoosobowym, które zatrudnia się krótkoterminowo, zadania, uprzednio realizowane przez nie same. Kierunek ten potwierdza szybki rozwój agencji zatrudnienia tymczasowego, co można zaobserwować na naszym rynku. Coraz częściej firmy poszukują kogoś na tzw. umowy na zastępstwo. Ludzie, w których przygotowanie i szkolenie firma zainwestowała spory kapitał, na skutek niepożądanych z punktu widzenia właścicieli firmy posunięć osobistych (zajście w ciążę), wyłączających ich czasowo z czynnego uczestnictwa w rynku pracy, są na tyle cenni, że organizuje się na zwolnione przez nich miejsca pracowników na zastępstwo. Umowy rozciągają się nawet na okres dwóch lat, po czym po ich wygaśnięciu przyjmuje się wcześniej związanego z firmą pracownika. Sytuację na zglobalizowanym rynku pracy trafnie oddaje hasło: No long term (Sennett 2006).

Sennett wskazuje też na inny ważny czynnik cementujący relacje społeczne, mianowicie na problem zaufania społecznego i autentycznych więzi pomiędzy ludźmi. Pośpiech i tymczasowość, a także wspomniana już elastyczność, absolutnie niwelują szanse na zawiązanie się głębszych relacji w miejscach pracy. Brakuje dla nich przede wszystkim niezbędnego czasu, w którym człowiek nabiera do drugiego w toku jego pracy, zaufania: „Nic na długo to zasada, która powoduje erozję zaufania i wzajemnych zobowiązań. Zaufanie może być, rzecz jasna, natury czysto formalnej, jak wówczas, gdy partnerzy zawierają umowę handlową lub liczą na wzajemne przestrzeganie reguł w grze. Zazwyczaj jednak głębsze zaufanie rodzi się w nieformalnych sytuacjach, na przykład gdy ludzie przekonują się, na kim mogą polegać w obliczu trudnego bądź niewykonywalnego zadania. Trzeba czasu, aby takie społeczne więzi mogły się rozwinąć, powoli zapuszczając korzenie w szczelinach sytuacji. Nastawienie na krótkotrwałość w nowoczesnych organizacjach nie pozwala dojrzewać takiemu nieformalnemu zaufaniu" (Sennett 2006, s. 24-25).

Odpowiedź na pytanie o możliwość i podatność naszych zachowań moralnych na oddziaływanie wielotorowych procesów globalizujących nasze życie jest trudna, ale, w moim przekonaniu, procesy te, choć nie zawsze jesteśmy tego świadomi, nasze zachowania moralne globalizują. Tezę swoją opieram na założeniu, że skoro globalizacja, która w sposób widoczny, odczuwalny i mierzalny wkroczyła w każdą dziedzinę życia, zmieniając nasze zachowania w zakresie form spędzania wolnego czasu, wyborów konsumenckich, relacji i form religijnych, sposobów spożywania posiłków, makdonaldyzując nie tylko same sposoby, ale i upodobania kulinarne, siłą rzeczy musi w znaczący sposób wpływać na nasze oceny otaczającego świata i ludzi, a nade wszystko na kryteria i sposoby wartościowania, wywołując eo ipso zmiany w zachowaniach o charakterze moralnym. Agresywna penetracja różnych form i przejawów naszego życia jako wynik procesów globalnych tworzy również zmiany w zakresie codziennych sądów wartościujących, które z kolei są pochodną naszych przekonań moralnych. 


\section{Spadek popytu na religię?}

\section{Religia jako zglobalizowany towar rynkowy}

Zastanawiając się nad skutkami procesów globalnych, nie sposób ominąć problemu zmian, które zaszły we współczesnych czasach płynnej religijności. Sparafrazowane nieco na opak określenie Baumana nich posłuży za pretekst do przyjrzenia się przekształceniom w zakresie nowych form odnoszenia się ludzi do kwestii religii oraz oceny z punktu widzenia siły oddziaływania religii na życie. Idąc tropem intuicji badawczej Vincenta Millera, również nie jestem zwolennikiem prostego przeciwstawiania kultury konsumpcyjnej - chrześcijaństwu. Za kulturą stoją określone wartości, akceptowalne przez jej zwolenników, ale i obecne w praktykach. Chcąc pojąć mechanizm zmian zachodzących w procesie myślenia kategoriami religii i o religii, musimy znaleźć klucz interpretacyjny, który te zmiany pozwoli uchwycić. Konfrontacja obu kultur może nas wyprowadzić jedynie na teoretyczne manowce.

Dzisiejszy problem tkwi, jak sadzę, nie w tym, w jaki sposób postrzegamy religię oraz jak wypełniamy przynależne jej praktyki, ale dlaczego uznanie jej orędzia i aprobata sposobów postępowania zupełnie nie przekładają się na zmiany w sferze życia praktycznego. Innymi słowy: „W jaki sposób praktyka kultury konsumpcyjnej może dokonać reorientacji znaczeń danej tradycji religijnej, powodując, iż nasze najbardziej szczere akty religijne okazują się niezdolne do przekształcenia praktyki naszego codziennego życia" (Miller 2007, s. 49). Problem jest tym bardziej interesujący, że znaczenia w sensie kulturowym można porównawczo odnosić do praktyki życia codziennego, o ile są stosowane przez jakieś grupy lub ich członków. Jeśli chodzi o tradycje religijne, na które składa się szereg wierzeń, rytuałów, świąt i symboli pozostają one obecne w kulturze, ale sytuują się raczej po stronie kultury duchowej. Wyraźny brak ich oddziaływania na wymiar praktyczny może poddawać w wątpliwość ich rangę w sensie znaczenia kulturowego. Należy pamiętać również o sieci instytucji stojących za określonymi religiami, których zadaniem jest m.in. dbałość o jakość nasycenia i przenikania praktycznej sfery życia treściami wypływającymi z religijnego orędzia. Z punktu widzenia naszych zainteresowań chodzi więc o to, w jaki sposób kultura konsumeryzmu, jako wynik uglobalnienia zachowań społeczeństwa klientów, dokonuje zmian w praktykach religijnych, że zmienia ich obraz oraz przekształca zachowania w odniesieniu do symboli, wartości czy form przeżywania doświadczeń religijnych.

Wydaje się, że w sytuacji gdy religia staje się jednym z wielu towarów rynkowych, ulega także mechanizmom, dzięki którym jako produkt się promuje. Nie bez znaczenia jest więc forma reklamy, w której religia, jako jedno z dostępnych dóbr, poddana zostaje wyeksponowaniu. Reklama z największym powodzeniem dociera tam, gdzie istnieje próżnia znaczeń i możliwych odniesień. Będąc jednym z wielu towarów na rynku, religia zaczyna funkcjonować jako bezpańska idea pozbawiona odniesień kontekstowych nakierowanych głównie na wspólnotę, która przydawałaby jej znaczenia. Aby oszacować wartość przedmiotu, należy odnieść go do innego lub innych, które stają się dlań tłem znaczeniowym i kryterium porównawczym. Funkcjonowanie samotnie eksponowanego przez reklamę towaru nie pozwala na dokonanie adekwatnego pomiaru jego przydatności lub wartości. Jeśli wartość ujawnia się w relacyjnej wymianie do innego towaru, to rodzi się pytanie: $\mathrm{Na}$ co i z kim da się wymienić religię jako propozycję dla współczesnego konsumenta kultury? 
Religia - przekaz dobrej nowiny i nadziei na pełniejsze i wartościowsze życie - może stać się przejawem miłości człowieka do określonego sacrum, któremu on stara się podporządkować świat swoich wartości i praktykę życia, czując się od owego sacrum zależnym. Problem tkwi w tym, że również miłość coraz łatwiej się merkantylizuje i - wziąwszy pod uwagę obserwacje Taylora - ulega dyktatowi rozumu instrumentalnego, by w efekcie podlegać rachunkowi strat i korzyści. W tym sensie pytanie: Dlaczego kochamy naszego Boga? można zamienić na pytanie: Co w Nim kochamy? Perspektywa ta uświadamia nam możliwe zmiany naszego spojrzenia na religię oraz nakazuje zredefiniować jej wartość dla naszego życia społecznego. Jeśli spojrzy się na analizy Weberowskie, dotyczące religii protestanckiej, widać, że upatruje się w nich katalizatora działań i sposobów samodoskonalenia moralnego oraz rozwoju gospodarczego. Wynika to z faktu, że religia nie izolowała człowieka od świata i że dzięki temu nie doszło do napięć pomiędzy religią a ekonomią (Ciupak 1986, s. 12). Religia, świat i człowiek stanowiły pewną całość. Współcześnie religia bywa odrywana od jej kulturowych kontekstów, od jej rozumienia jako trwale wpisanej i istotnej idei, organizującej w dziejach strukturę społeczną. Jest jedną z wielu, po którą, podobnie jak po towar, można sięgnąć, użyć i szybko się znudzić, dokonując wyboru innej. Bez odniesienia kontekstowego traci swój rzeczywisty wymiar społeczno-kulturowy, stając się pozbawioną odniesień. Jest jednym z towarów szerokiego asortymentu oferowanego przez rynek. Takie ujęcie zrodziło zmiany w jej odbiorze oraz $\mathrm{w}$ formach przeżyć religijnych.

Te zmiany, podobnie jak inne, są wynikiem globalizowania się religijności. Nie chodzi o próbę oceny zjawiska nowej religijności, ale o uchwycenie mechanizmów tych zmian i ich związ$\mathrm{ku} \mathrm{z}$ procesem marginalizacji pewnych grup społecznych. W sytuacji narastającego kryzysu instytucjonalnych form wyznawania religii, z czym niewątpliwie mamy do czynienia, ludzie w poszukiwaniu sensu własnej egzystencji sięgają po rozmaite w dosłownym tego słowa znaczeniu elementy wierzeń, często doktrynalnie i kulturowo odległych, a nawet ze sobą sprzecznych. Wśród badaczy charakteryzujących współczesność pod kątem cech kulturowych wymienić należy choćby G. Simmla, dostrzegającego w nowoczesnej kulturze poczucie utraty sensu. Tworzenie go w sytuacjach indywidualnego wyboru, nieokreśloności i przygodności jest z gruntu trudniejsze niż w warunkach trwałych fundamentów etycznych. One, gwarantując względną stabilizację, stanowiły oś, wokół której można nadbudowywać wartości dodane w postaci sensów subiektywnych. Zupełny brak podłoża o charakterze aksjologicznym nie pozwala na wytyczenie choćby wskaźników kierunkowych do zawiązania się początkowego szlaku budowania indywidualnej drogi, bowiem redundancja treści i hiperpluralizm sensów sprawiają, że jednostka, nie radząc sobie z racjonalnym wyborem, odstępuje od czynności wyboru. Ratuje się w ten sposób od przytłaczającego chaosu i nadmiaru treści, których nie jest w stanie ogarnąć i zweryfikować pod kątem ich przydatności dla procesu budowania sensu własnej egzystencji: „Jednostka nadaje swojemu życiu sens, kształtując własne „światy sensu”, strzegąc swojej autonomii i niezależności. Żyje coraz częściej w świecie niedoboru ideałów, wartości i norm, w świecie ,małych” sensów, sensów bez głębi, pozbawionych wzniosłości, a zwłaszcza w warunkach zanikania wiążącego dla wszystkich sensu życia” (Mariański 2010, s. 42).

Religia, pełniąc do niedawna rolę dostarczyciela takich sensów i organizatora relacji społecznych, poprzez zewnętrzne przejawy kultu i manifestacje wiary, stawała się elementem znacząco wpływającym na procesy integracyjne członków społeczeństwa religijnego. Dziś, gdy należy mówić bardziej o różnych typach duchowości, tj. o indywidualnych dążeniach mających na celu dostarczenie sensu dla pojedynczego życia, ten aspekt religii wskazuje, że wytraciła swą moc integracyjną i normatywną. W zaistniałej sytuacji, ludzie, pozostając wiernymi dawnym praktykom i znaczeniu religii w ich życiu, mogą mieć poczucie jedynych 
wyznawców, których praktyki i oddanie instytucjonalnym formom religijnym gwarantują rzeczywistą obronę ortodoksji. Poczucie to wpływa na wzmocnienie separatystycznych nastrojów, w których ujawnia się forma osamotnienia społecznego i można ją interpretować pod kątem wzrostu procesu atomizacji. W tym sensie religia może stać się czynnikiem swoistego wykluczenia.

Z drugiej strony, zmiany w formach przeżyć religijnych, mające, jak sądzę, źródło w indywidualizmie, kierują poszukiwacza sensu własnej egzystencji w stronę samodzielnych odkryć, co stwarza całkiem inne zagrożenia. Utrata więzi ze wspólnotą religijną zorganizowaną wokół instytucji, której skutkiem jest stan kryzysu instytucjonalnych form przeżywania doświadczeń religijnych zmusza wyznawców do poszukiwania na własną rękę możliwych do zaakceptowania doktryn. Rodzi to pewne problemy, przede wszystkim w sensie zachowania odrębności wiary opartej na zdrowej, tj. zgodnej z ortodoksją takiego lub innego wyznania, nauce. Aktywny również w tej sferze rozum instrumentalny sprzyja eklektyzmowi elementów zaczerpniętych z różnych wyznań. Skutek jest taki, że ludzie nie potrafią konkretnie określić własnej tożsamości religijnej i mają trudność w sformułowaniu odpowiedzi na pytanie, jakiej religii są wyznawcami. Nadmiar treści czerpanych z różnych źródeł przyczynia się w znacznym stopniu do poczucia braku zakorzeniania w takiej lub innej tradycji. Rozmywają się zatem granice największych religii, dbających usilnie o wysoki poziom autoidentyfikacji swego wyznania, choćby poprzez odwołanie do wielkich ksiąg, których treść bywa uświęcona wielowiekową tradycją. W sytuacji konglomeratu niespójnych treści czerpanych z często odmiennych i obcych kulturowo źródeł rodzi się poczucie osamotnienia jednostki i wzmacnia poczucie oderwania, sprzyjając procesowi dezintegracji społecznej.

Ciekawa pozostaje także kwestia łatwego zaaprobowania takich połączeń przekonań, które z punktu widzenia potocznej logiki muszą budzić co najmniej zdziwienie. Czy można zaakceptować przekonanie o rekoncyliacyjnej i soteriologicznej misji np. Chrystusa z jednoczesnym przyjęciem lub wiarą $\mathrm{w}$ treści płynące $\mathrm{z}$ doktryny metempsychozy? Jeśli tak jest, a potwierdzają to badania socjologów religii (Baniak, Mariański, Inglehart, Giddens), to na podstawie tego typu zachowań swoją siłę ponownie ujawnia skrajny $\mathrm{i}$ - w tym wypadku - dyletancki indywidualizm. Używam określenia dyletancki dlatego, że nie licząc się z prawidłami podstawowych zasad racjonalności, nie tylko nie dba o spójność indywidualnie konstruowanej doktryny, ale nie liczy się także z horyzontami znaczeń, które budują polistrukturę, przydając religii określonego znaczenia. Sam więc wybór lub arbitralna decyzja co do wartości takiego a nie innego układu elementów różnych doktryn stają się tedy wystarczającym gwarantem uznania i domagają się prawa do ich kwalifikacji jako wyborów równoprawnych i ważnych. Znowu więc zwykła czynność wyboru posiadać ma moc obdarzania jakiejkolwiek treści znaczeniem.

Nie wydaje się, aby religia w czasach nowoczesnych była w odwrocie. Mamy raczej do czynienia z procesem prywatyzacji wiary i należy dziś mówić o duchowości (duchowościach) jako samodzielnej drodze poszukiwania intymnego kontaktu z sacrum niż o religii. To niewątpliwie wynik zmian w postrzeganiu instytucji kościelnych, ale i skutek liberalizacji życia społecznego, jak też procesu pluralizacji różnego typu propozycji duchowych podsuwanych przez bogatą ofertę rynkową. Załatwia się przy tym ważną kwestię społecznych potrzeb: każdy znajdzie coś dla siebie, tj. ci, którzy są spragnieni twardej ortodoksji mogą odnaleźć się np. u lefebrystów, ci, dla których liczy się wzniosła oprawa i patos znajdą je w bogatej formie liturgii kościołów wschodnich, inni, którzy przykładają większą wagę do zdrowia, mogą uprawiać jogę lub oddać się innym praktykom religii Wschodu, inni mogą zwrócić się ku grupom wskazującym na potrzebę zadbania o środowisko itd. Rynek, komercjalizując religię oraz sposoby jej przeżywania, przekształca relację ja - sacrum w stosunek sacrum (towar) - klient. 
W społeczeństwach znajdą się pewnie i tacy, którzy nigdzie odnaleźć się nie mogą. Mogą więc stworzyć własną postać duchowości i z uwagi na fakt, że jest to ich wybór, nikt nie będzie mógł poddać w wątpliwość jego ważności (choćby z punktu widzenia koherencji treści, czyli logiki), bo wybór legitymizuje wszystko: „Coraz popularniejszy staje się przy tym pogląd, że każdy ma prawo do wyboru własnych wartości i norm oraz że nikt nie powinien narzucać ich innym ludziom (co można określić jako swoisty ekumenizm religijny i moralny)" (Mariański 2010, s. 16). O ile prawo do wyboru jest postulatem bezdyskusyjnym, o tyle sama treść tego wyboru, bez narażenia się na zarzut absurdalności, poddaje się wartościowaniu i żaden wybór jako jedna z wielu codziennie dokonywanych czynności, nie może stanowić o znaczeniu wybranych treści: „Rzeczy nabierają znaczenia w relacji do tła sensowności. Nazwijmy je horyzontem. Z tego wynika, że jedną z rzeczy, których nie możemy zrobić - jeśli mamy się znacząco samookreślić - jest stłumienie albo zanegowanie horyzontów, na których tle rzeczy nabierają dla nas znaczenia. Ale taki właśnie samobójczy krok stawia się często w naszej subiektywistycznej cywilizacji. Głosząc prawomocność wyboru jednej z możliwości, bardzo często pozbawiamy zarazem obu możliwości ich znaczenia” (Taylor 2002, s. 41).

\section{Wykluczenie czy rezygnacja? Oto jest pytanie!}

Narcystyczna kultura naszych czasów nasycona jest nade wszystko łatwym relatywizmem (Taylor 2002). Oznacza to, że każdy ma własne wartości, o których nie tylko nie da, ale i nie powinno się dyskutować. W kontekście działań komunikacyjnych człowieka, które miały sprawić, że zaczniemy budowanie społeczeństwa dyskursywnego, obliczonego na consens, swą odśrodkową siłę ujawniają postawy skutecznie eliminujące takiego typu roszczenia. Dyskusja jako narzędzie umożliwiające nie tylko przekazywanie treści, ale nade wszystko wypracowanie wspólnych stanowisk została brutalnie odtrącona przez samych użytkowników języka. Rezygnacja $z$ języka jako podstawowego medium dialogu oznacza proces postępującego „zwijania” własnej egzystencji, pragnącej przeżywać siebie i swe życie w formie wystawnej uczty dla jednej osoby - dla siebie. Skutek jest taki, że ograniczając swą aktywność do własnego świata, rezygnuje tym samym $z$ różnorodności i bogactwa form oferowanych przez innych i świat interpretowany jako suma dorobku wielu pokoleń. Szukając celnego porównania opisującego tę sytuację, na myśl przychodzi jedynie samounicestwienie.

Tendencja do traktowania tego, co poza mną jako Nie-Ja, znana choćby z koncepcji idealizmu subiektywnego Fichtego, staje się powszechnym zachowaniem naszych czasów. Różnica polega na tym, że dla Fichtego owo Nie-Ja było sferą, w której Ja chciało utwierdzać swe wartości, humanizując przez to irracjonalną rzeczywistość świata pozapodmiotowego. Nie-Ja stawało się więc niezbędnym korelatem umożliwiającym podmiotowi urzeczywistnienie celów moralnych, zaś w nowoczesności Nie-Ja osiągnęło status upiora, przeszkody, słowem - czegoś, czyhającego na Ja. W tym sensie jest z gruntu czymś obcym dla refleksji Fichteańskiej. Problem ten dostrzega Taylor, który, charakteryzując indywidualizm, pisze, że „oznacza [on - przyp. T.T.B.] skupienie się na sobie, a w konsekwencji oderwanie od (a nawet nieświadomość) szerszych kwestii czy problemów - religijnych, politycznych bądź historycznych - wykraczających poza jednostkę. To wszystko prowadzi do zawężenia i spłaszczenia życia” (Taylor 2002, s. 21). Czyż nie przypomina to drogi do samozagłady podmiotu?

Jeśli zgodzimy się z tezą, że żyjemy w czasach powszechnej konsumpcji, to musimy także wiedzieć, że ten styl życia wpływa zarówno na nasze codzienne wybory, zachowania moralne, jak i kształtuje współczesną wrażliwość. W świecie konsumpcji nie ma zbytnio miejsca na relacje dialogiczne, bowiem takowe nie są nikomu potrzebne. Społeczeństwo wymiany handlowej jest zbiorem zatomizowanych jednostek, mającym amorficzną strukturę, w której 
każdy jest potencjalnym właścicielem określonego towaru - dobra konsumpcyjnego. Problem w tym, żeby na jego towar był popyt. Jeśli podaż przewyższa popyt, taki człowiek sytuuje się poza grupą osób przydatnych dla innych, nie jest bowiem w stanie zaspokoić ich potrzeb. Ludzie świadczący wzajemne usługi mają prawo oczekiwać od innych, że ci także mają coś interesującego do zaoferowania. Grupa handlująca tym, co wyszło z mody, co nie jest już aktualne, jest eliminowana z rynku, ponieważ wprowadza do obiegu towar przeterminowany. Analogicznie można powiedzieć, że jej przydatność dla innych również się przeterminowała. Trzeba nieustannie nadążać za potrzebami i umieć przewidywać trendy oraz kursy. Kto lepiej opanuje tę sztukę, wciąż będzie potrzebny.

Powyższa charakterystyka społeczeństwa świadczącego wzajemne usługi sprowadza się do postrzegania innych jako narzędzi do zaspakajania efemerycznych potrzeb. Instrumentalizm i reifikacja podmiotowości ludzkiej wpływa znacząco na zmiany w zakresie relacji szacunku i rodzi obawę o kryzys uznania. Bolączki te maja istotny wpływ na nasze codzienne relacje z innymi, czego najlepszym przykładem jest stały spadek zaufania społecznego, powszechna agresja, nieliczenie się z prawami innych, powszechnie akceptowane kłamstwo oraz cwaniactwo. W społeczeństwach gospodarki wolnorynkowej potrzeba uznania realizowana jest na ogół przez zasobność portfela, a nie z tytułu przysługującej każdemu godności i ontologicznej kwalifikacji jako podmiotu: ,kapitalizm wytwarza ogromne bogactwo, lecz mimo to nie zaspokaja ludzkiego pragnienia równego uznania, czyli izotymii. Wraz z podziałem pracy rodzą się różnice godności poszczególnych zawodów: śmieciarze i podkuchenni zawsze będą mniej szanowani niż neurochirurdzy i gwiazdy futbolu, a jeszcze mniej godności mieć będą bezrobotni. Ludziom biednym czy bezdomnym dzieje się krzywda nie tyle fizyczna, ile moralna. Ponieważ nie posiadają własności, pozostała część społeczeństwa ich lekceważy: nie umizgują się do nich politycy, a policja i sądownictwo z mniejszym zapałem walczą o ich uprawnienia; mogą znaleźć tylko taką pracę, która ich poniża; wreszcie mają mniejsze szanse na poprawę swej sytuacji przez edukację lub inny sposób samorealizacji. Dokąd będzie istniało rozróżnienie na ludzi bogatych i biednych, dotąd pewne zawody będą uchodziły za godne szacunku, a inne za godne pogardy, dotąd żaden wzrost bezwzględnego poziomu dobrobytu społeczeństwa nie usunie szkód jakich codziennie doznaje godność ludzi gorzej sytuowanych” (Fukuyama 1997, s. 134).

Pojawiające się przypadki świadomej rezygnacji z aktywnej formy uczestnictwa w życiu społecznym, które kwalifikowane są przez większość jako niewytłumaczalne wybryki, dziwią i sprawiają kłopot interpretacyjny. Wykluczenia społecznego nie można więc mylić z indyferentyzmem lub świadomym działaniem polegającym na samoograniczeniu uczestnictwa i aktywności. Co prawda, to również jest wykluczenie, ale z wyboru. Z wykluczeniem społecznym jako zjawiskiem społecznie niepożądanym mamy do czynienia wtedy, kiedy dochodzi do sytuacji, w której ludzie, grupy lub nawet narody chcą uczestniczyć w życiu szerszej zbiorowości, ale nie wiedzą, w jaki sposób to czynić albo też na drodze prowadzącej do ich uczestnictwa stoją przeszkody polityczne, ekonomiczne lub kulturalne, których własnymi siłami nie są w stanie pokonać. Ludzie o indyferentnych nastrojach nie chcą uczestniczyć w życiu politycznym lub ekonomicznym dlatego, że nie uznają tych dziedzin za istotne dla własnej pomyślności lub inaczej niż reszta społeczeństwa definiują to, co zwykło się uznawać za udane życie.

Analizując skutki wykluczenia społecznego, najbardziej widocznymi są etyczne i społeczne implikacje tego zjawiska. Zaniechanie uczestnictwa w życiu społecznym poprzez pracę, wpływa na poczucie odrzucenia. Choć wykluczony, człowiek i tak zdany jest na społeczeństwo; musi w jego obrębie przebywać i ponosić konsekwencje tego faktu. Wykluczonym ciężko zaakceptować nową dla nich sytuację. Będąc skazanymi na odrzucenie przez innych lub przez 
często niezrozumiałe mechanizmy rynkowe, odnoszą wrażenie bycia gorszymi i skrzywdzonymi. Sprzyja to procesom alienacji. Wewnętrzne poczucie izolacji jest na tyle silne, że uniemożliwia powrót do czynnego udziału w społeczeństwie. Świadomość nienadążania za krokiem społeczeństwa i permanentnie zmieniającym się światem, technologiami, informatyzacją, staje się zarzewiem konfliktów wewnętrznych i ma psychologiczne podłoże. Bywa, że stymuluje posunięcia o charakterze eskapistycznym. Stąd pojawiające się rzesze ludzi pragnących świadomie żyć na marginesie społeczeństwa nawet za cenę znacznego obniżenia standardu życia. Problem ten jest ważny w kontekście debaty o zasadność i sposób implementacji zasad tzw. ekonomii społecznej. Stopień trudności w pozyskiwaniu wyłączonych i przywracaniu ich społeczności pracujących jest ogromny.

Przed samorządami oraz organizacjami pozarządowymi wielkie zadanie: Jak zmotywować grupy, które po wielu nieudanych próbach nie chcą już brać udziału w podziale pracy? Ludzi tych do poszukiwań źródeł dochodu nie motywuje chęć bycia aktywnym, dotrzymania kroku, ale często fatalna sytuacja materialna. W desperacji podejmują pracę poniżej kwalifikacji, godząc się na krótkotrwałe i niepewne formy zatrudnienia. Pozostają więc w stałej dyspozycji i gotowości do podjęcia każdej pracy, często po zaniżonych stawkach. To rodzaj aktywności motywowanej nie poczuciem ducha przedsiębiorczości, ale skutek strachu przed wizją nędzy i upodlenia. Inną przeszkodą na drodze aktywizacji zawodowej jest zaawansowany wiek wykluczonych. Wykluczony ma poczucie osamotnienia w zmaganiu o utrzymanie poziomu swego już nie życia, ale człowieczeństwa. Z punktu widzenia ekonomii wykluczenie niekiedy bezpowrotnie niszczy siły i zdolności ludzkie, zaś z perspektywy społecznej, inicjuje proces erozji życia rodzinnego, skutecznie blokując dostęp do dochodu jako podstawy jej egzystencji.

Zarówno geneza, jak też skutki procesów globalizacji nie do końca zostały rozpoznane, ale same procesy niewątpliwie odcisnęły na tyle trwałe piętno społeczne i kulturowe, że nie da się tej oczywistości w żaden sposób zaprzeczyć. Dążenie za wszelką cenę do autentyczności, będącej aspektem nowoczesnego indywidualizmu, charakteryzuje się tym, że kładzie nacisk na wolność jednostki. Jednak problem leży gdzie indziej. Wydaje się, że ta powszechna akceptacja dla autentyczności, niepowtarzalności i nieskrępowania jednostki zdradza, że jako ludzie współcześni mamy coraz większy problem z wolnością. Nie idzie o to, jak ją zdefiniować. Z klasyfikowaniem i tworzeniem teorii na ogół dobrze sobie radzimy. Chodzi raczej o jej rozumienie. Paradoksem naszych czasów może okazać się fakt, że gdy cały świat w szaleństwie i nieograniczeniu pochłonięty jest wzmożonym wysiłkiem mającym na celu uwolnić jak najwięcej wolności, wywalczył coś, co okazało się jego przekleństwem i nieszczęściem zarazem.

Wolność nie jest wartością, którą można zamknąć w definicji. Jest problematyczna, ponieważ jest ważna i jak każdy problem domaga się odpowiedzi, a nade wszystko - zdefiniowania w działaniu. Póki co, wydaje się, że to przedsięwzięcie jest jeszcze dla nas zbyt trudne. Podobnie rzecz ma się z tożsamością. Kształtuje się ona w najbardziej dla człowieka naturalnej sytuacji, w dialogu z innymi. Jeśli jest zgodna z opinią tych, którzy nas widzą i z nami żyją, to dobrze, ale równie dobrze jest wtedy, gdy pomiędzy naszymi odczuciami a odczuciami innych jest różnica. Ważne, by był punkt odniesienia, a jego najbardziej autentyczną i wartościową rolę pełnić może jedynie drugi człowiek. Tożsamość jest na tyle istotną wartością, że gdy ją posiadamy, łatwiej nam znosić naszą inność i wykluczenie, nie musimy uporczywie zabiegać o uznanie, bowiem jest ono zawarte w jej istocie. Jest tym bardziej widoczna i wyraźna, o ile rozciąga się na drugiego człowieka: „Odkrywanie własnej tożsamości nie oznacza, że odkrywamy ją w osamotnieniu, lecz raczej, iż negocjujemy ją w ramach dialogu - częściowo jawnego, częściowo zinternalizowanego - z innymi” (Taylor 2002, s. 50). 


\section{Literatura}

1. Baniak J., 2007, Desakralizacja kultu religijnego i świąt religijnych w Polsce. Studium socjologiczne, Kraków.

2. Beck U., 2002, Społeczeństwo ryzyka. W drodze do innej nowoczesności, przeł. S. Cieśla, Warszawa.

3. Borgman A., 1984, Technology and the Character of Contemporary Life, Chicago.

4. Brzozowski T.T., 2003, Technika jako taktyka zagrażająa wspótczesnej egzystencji? Aktualność Spenglerowskiej krytyki kultury maszyn, ,Zbliżenia Polska - Niemcy”, nr 2 (35), 2003, s. 146-157.

5. Ciupak E., 1982, Religia i religijność, Warszawa.

6. Doświadczenie religijne, 2007, oprac. T. Doktór, Warszawa.

7. Fukuyama F., 1997, Ostatni człowiek, przeł. T. Bieroń, Poznań.

8. Giddens A., 2001, Nowoczesność i tożsamość, przeł. A. Szulżycka, Warszawa.

9. Giddens A., 2008, Socjologia, przeł. A. Szulżycka, PWN, Warszawa.

10. Mariański J., 2010, Religia w społeczeństwie ponowoczesnym, Warszawa.

11. Miller J. V., 2007, Religia w świecie konsumpcji, przeł. T. Szafrański, Warszawa.

12. Norris P., Inglehart R., 2006, Sacrum i profanum. Religia i polityka na świecie, Kraków.

13. Rifkin J., 2001, Koniec pracy, przeł. E. Kania, Wrocław.

14. Rifkin J., 2008, Entropia - nowy światopogląd, przeł. B. Baczyńska, Katowice.

15. Spengler O., 2001, Zmierzch Zachodu, przeł. J. Marzęcki, KR, Warszawa.

16. Sennett R., 2006, Korozja charakteru. Osobiste konsekwencje pracy w nowym kapitalizmie, przeł. J. Dzierzgowski, Ł. Mikołajewski, Warszawa.

17. Taylor Ch., 2002, Etyka autentyczności, przeł. A. Pawelec, Kraków.

18. Taylor Ch., 2006, Oblicza religii dzisiaj, Kraków.

19. Taylor Ch., 2010, Nowoczesne imaginaria społeczne, przeł. A. Puchejda, K. Szymaniak, Kraków.

\section{Globalization and the Exclusion from Society. Ethical and Cultural Origin of the Social Marginalization}

The Author of this paper studies the impact globalization processes on socio-cultural changes, which lead to social exclusion. Being out of a society has different origins especially in modern world and modern society. A reason does not always lie only on the man's side. Being out of a society is sometimes a result of many different processes like, in my opinion, the most essential ones - global trends and the especially ambiguous process - globalization.

The Author pays attention to the origins of the social marginalization and tries to show the most important ones. Simultaneously, he analyzes them by looking at the intensity of their impact on social marginalization. This article ends with an unaided commentary in which the author passes his judgment on the origins and degree of influence of above-mentioned issues. 